\title{
Impact of Intervention on Reproductive Health knowledge of Rural Mothers
}

\author{
Nasreen Banu* and K. Yashoda \\ ${ }^{1}$ AICRP- H.Sc (All India Coordinated Research Project - Home Science), Human \\ Development Component, ${ }^{2}$ AICRP-H.Sc, Human Development Component, \\ PGRC, PJTSAU (Professor Jayashankar Telangana State Agricultural University), \\ Rajendranagar, Hyderabad - 30, Telangana State, India
}

*Corresponding author

\section{A B S T R A C T}

\section{Keywords}

Reproductive health, Intervention programme, Rural families

Article Info

Accepted:

15 October 2018

Available Online:

10 November 2018
Present study was taken up to find out the Knowledge levels of the Rural mothers (with children between 2-5 years) in the adopted villages of Maheshwarammandal, RR district, Hyderabad with regard to Reproductive health issues. 75 Married women (First time pregnant) formed the sample for the present study. Checklist was developed to find out the Knowledge levels of Rural mothers. Based on the results, Knowledge based Intervention programmes were organized. Impact assessment showed significant improvement in the Knowledge levels of the sample, reflecting the effectiveness of the Intervention programme.

\section{Introduction}

Reproductive health covers all aspects of women's health. It is an umbrella concept, consisting of several distinct, yet related issues such as abortion, child birth, sexuality, contraception and maternal mortality. Biological, social, cultural, economical and behavioral factors play an important role in determination of reproductive health (Singh et al., 1995). The social construction of sexuality and the resultant gender relation plays a crucial role in shaping women's life and health conditions.

Over $75 \%$ of Indian population resides in rural area in India. Approximately $30 \%$ of women are married between the ages of 15 - 19 years. This is normally followed by closely spaced pregnancies. The state of Rajasthan located in northwestern India, has highest level of early marriage in India, almost one out of every three girls between the ages of fifteen to nineteen is married. The prevalence of early 
marriage and general lack of literacy among many Rajasthani girls has created an urgent need of effective sexual and reproductive health education programs (Singh, 2004). There is overwhelming evidence that child marriage is occurring in Rajasthan in large numbers, despite laws against it. Large numbers of girls from poor households are pushed into early marriage, which is consummated almost immediately after menarche (Santhya and Jejeeboy, 2003). Early marriage leading to early motherhood is associated with serious health problems to adolescent mothers and their offspring.

\section{Operational definition}

Knowledge: Knowledge is a familiarity, awareness, or understanding of someone or something, such as facts, information, descriptions, or skills, which is acquired through experience or education by perceiving, discovering, or learning.

According to Webster's dictionary, knowledge is 'the fact or condition of knowing something with familiarity gained through experience or association'. In practice, though, there are many possible, equally plausible definitions of knowledge. A frequently used definition of knowledge is "the ideas or understandings which an entity possesses that are used to take effective action to achieve the entity's goal (s).

Agrarian families: Families involved in Agriculture for their livelihood

Intervention: An intervention is a combination of programme elements or strategies designed to produce behavior changes or improve health status among individuals or an entire population.

Reproductive health: Reproductive health refers to the diseases, disorders and conditions that affect the functioning of the male and female reproductive systems during all stages of life.

Reproductive health is a state of complete physical, mental and social well-being, and not merely the absence of reproductive disease or infirmity. Reproductive health deals with the reproductive processes, functions and system at all stages of life.

Maternal health: It refers to the health of women during pregnancy, childbirth and the postpartum period. While motherhood is often a positive and fulfilling experience, for too many women it is associated with suffering, ill-health and even death.

Child health: It is a state of physical, mental, intellectual, social and emotional well-being and not merely the absence of disease or infirmity. Healthy children live in families, environments, and communities that provide them with the opportunity to reach their fullest developmental potential.

\section{Materials and Methods}

Sample was identified from the adopted villages (5) of Maheshwarammandal, RR District, Hyderabad, through field survey and focused group interviews with the help of the AWWs, ANMs, and Women Self help Group leaders in the village.

It's a quasi-experiment study. It is an empirical interventional study used to estimate the causal impact of an intervention on its target population without random assignment.

There were 357 married women having children between the age group of 2-5 years in the selected clusters of 5 villages of Maheshwarammandal and 75 formed the sample for the present study. The following 
criterion was used to select the sample. Purposive sampling procedure was used.

\section{Criteria for sample selection}

- Women who were married and living with their husband

- Women who were having children (between $2-5$ years)

- Women who were willing to participate in the project

\section{General objective}

Promoting Reproductive health Knowledge among Rural mothers from Agrarian families

\section{Specific objectives}

To find out the demographic profiles of the Selected sample

To find out the Knowledge levels of the Selected sample with regard to Reproductive health

To develop suitable IEC material for promoting Reproductive health among the selected sample

To conduct Knowledge based Intervention programme to the selected sample

To assess the impact of the Intervention programme on the Knowledge levels of the selected sample

\section{Research strategy adopted}

In order to achieve the above objectives, Knowledge based Intervention programmes were organized for the Married women, using the developed IEC material.

\section{Materials and Methods}

\section{Research tools details}

SES scale developed by Aggrawal et al., (2005) was used to find out the SES of the
Rural families. Scoring was given as per the norms provided in the manual. It is a standardized scale, used to assess the family background information of the individuals, which includes parameters like educational and occupational status of parents, number of siblings, material possession, kind of locality, presence of farm animals, land holdings, number of earning members in the family etc. The scale categorizes the sample on: Upper High; High; Upper middle; Lower middle; Poor and Very poor Socio Economic Status.

Reproductive health awareness checklist was developed by AICRP-CD, Hyd Unit (2017) to find out the Knowledge levels of Married women with regard to Reproductive health issues. The Reliability Value of the checklist is: 0.81 . The checklist comprises of 5 dimensions:

Pre-conception health: It is the First dimension and has 26 statements. It measures the knowledge levels of the sample in the following 4 areas: Preparation for Parenthood (7 statements); Factors that Boost Preconception Health (8 statements); Preparedness for pregnancy (5 statements); and Preconception Behaviours (6 statements).

Reproductive health problems: It is the Second dimension and has 31 statements. It measures the knowledge levels of the sample in the following 4 areas: Menstrual problems (9 statements); Menstrual hygiene practices (6 statements); Potential risks to health due to poor menstrual hygiene (4 statements); Gynecological problems (12 statements).

Family planning: It is the Third dimension and has 17 statements. It measures the knowledge levels of the sample in the following 3 areas: Family Planning Methods (5 statements); Purpose of following Family planning methods (4 statements); Contraceptive related problems (8 statements). 
Sexually transmitted diseases: It is the Fourth dimension and has 36 statements. It measures the knowledge levels of the sample in the following 5 areas: Awareness about HIV/AIDS \& related problems (8 statements); Awareness about RTI/STD related problems (11 statements); Awareness about transmission of HIV / AIDS (9 statements); Preventive methods for HIV/AIDS (3 statements); Preventive methods for RTI/STD (5 statements).

General: It is the Fifth dimension and has 30 statements. It measures the knowledge levels of the sample in the following 3 areas: Services Related to Reproductive Health (10 statements); Awareness about marital laws \& legal rights (9 statements); Awareness about Reproductive rights (11 statements).

There are all together 140 statements (all 5 dimensions). Each statement is arranged on 3 point scale ie aware is marked as 3; aware but not sure 2; Not sure as 1 . The total scores were further grouped as Low, Average and high. Higher the score, higher is the level of Knowledge in that particular dimension.

\section{Results and Discussion}

\section{Demographic data on married women}

There were 961 married women from the selected clusters of adopted villages, Maheshwarammandal, RR district. Out of 961 married women, $37 \%$ (357) were having children between $2-5$ years and 75 formed the sample for the present study.

The table 1 depicts the Age wise distribution of Rural mothers with children (between 2 -5 years). Out of the total sample 75 , less than half of $(44 \%)$ were in the age range of 26-30 yrs; $33 \%$ were in the age group of 20-25 yrs and the remaining $23 \%$ were in the age group of 31-35 yrs.
The table 2 depicts the Education wise distribution of Rural mothers with children (between $2-5$ years). Out of the total sample 75 , thirty six percent of the sample completed Secondary school; $31 \%$ completed Inter; $22 \%$ completed Primary school; $7 \%$ were illiterates and only $4 \%$ were pursuing their degree.

The table 3 depicts the Occupation wise distribution of Rural mothers with children (between $2-5$ years).

Out of the total sample 75 , forty four percent of the sample were fully involved in agriculture; $37 \%$ were partially involved in agriculture; $12 \% \%$ were housewives; and only $7 \%$ were running petit business.

The table 4 depicts the Socio Economic Status of Rural mothers with children (between 2 - 5 years). Out of the total sample 75 , more than half of $(60 \%)$ the sample were in lower middle income level; $20 \%$ were in poor economic status; $17 \%$ were in upper middle income level and only 3\% were in high income group.

The table 5 traces the pretest scores of Rural mothers with children (between $2-5$ years) with regard to Reproductive Health. The Self structured Checklist covers 5 dimensions.

With regard to Preconception Health dimension, out of 75 , more than half $(58 \%)$ of the sample obtained Average scores; 27\% obtained High scores and 15\% obtained Low scores.

With regard to Reproductive health problem dimension, less than half $(52 \%)$ of the sample obtained Average scores; 37\% obtained High scores and $11 \%$ obtained Low scores.

With regard to Family planning dimension, more than half $(52 \%)$ of the sample obtained Average scores; 35\% obtained High scores and $13 \%$ obtained Low scores. 
With regard to Sexually transmitted diseases dimension, less than half $(45 \%)$ of the sample obtained Average scores; 37\% obtained High scores and $18 \%$ obtained Low scores.

With regard to General dimension, slightly more than half $(55 \%)$ of the sample obtained Average scores; $28 \%$ obtained Low scores and $17 \%$ obtained High scores.

Planning \& preparing educational material for conducting Awareness programmes on issues concerning Reproductive Health care among married women

Based on the bench mark issues and preassessment results, videos, brochures, leaflets, resource books and educational posters were planned / developed on selected thematic areas.

Educational posters mainly focused on: Adolescent Reproductive health; Balanced diet during Pregnancy; Birth control facts; Benefits of Breast feeding; Comprehensive nutrition; Condom use; Contraception choices; Healthy pregnancy; HIV prevention; Transmission of AIDs; Transmission of STI/ RTI; Reproductive rights; Reproductive problems; Reproductive health; Antenatal care; Immunization schedule; Menstrual hygiene; Menstrual problems; Menstrual education; Neonatal health; Sanitary napkin; STI symptoms

Videos mainly focused on: Effective Family planning methods; Importance of Breast feeding; Care during Pregnancy; Diet during Pregnancy; Immunization Schedule to be followed; Transmission of AIDs; Transmission of STI/ RTI; Importance of Reproductive Health; Antenatal Care; Reproductive rights; Menstrual problems; Danger symptoms of Pregnancy; HIV prevention; Healthy pregnancy; Reproductive Health; Maternal \& Child health services.
Some of the intervention strategies used for promoting Reproductive Health Knowledge among the sample was: group exercises, role plays, open ended stories, Brain storming, Group activities, Situation analysis, Case studies, Responding to real life situations and Group discussions etc.

Conducting programmes on Reproductive Health care: Knowledge based Capacity building programmes (25) were conducted for married women from the adopted villages on issues concerning Reproductive Health care. A comprehensive health education program was organized in 20 sessions for this group of rural mothers. Each session was of two hours duration conducted on three consecutive days. The training methods included a didactic lecture followed by interactive sessions with the mothers to clarify doubts.

The table 6 traces the post-test scores of Rural mothers with children (between 2 -5 years) with regard to Reproductive Health Knowledge.

With regard to Preconception Health dimension, out of 75 , more than half $(60 \%)$ of the sample obtained High scores; 39\% obtained Average scores and only $1 \%$ obtained Low scores.

With regard to Reproductive health problem dimension, less than half $(48 \%)$ of the sample, obtained High scores; 47\% obtained Average scores and only $5 \%$ obtained Low scores.

With regard to Family planning dimension, more than half $(53 \%)$ of the sample obtained High scores; 44\% obtained Average scores and only $3 \%$ obtained Low scores.

With regard to Sexually transmitted diseases dimension, less than half (49\%) of the sample obtained High scores; 44\% obtained Average scores and only $7 \%$ obtained Low scores. 
Table.1 Age wise distribution of the Selected sample (N=75)

\begin{tabular}{|r|c|c|c|}
\hline $16-19$ yrs & $20-25$ yrs & $26-30 y r s$ & $31-35 y r s$ \\
\hline N \& \% & N \& \% & N \& \% & N \& \% \\
\hline---- & $25(33 \%)$ & $33(44 \%)$ & $17(23 \%)$ \\
\hline
\end{tabular}

Table.2 Education wise distribution of the Selected sample (N=75)

\begin{tabular}{|r|l|l|l|l|}
\hline Illiterate & $\begin{array}{l}\text { Primary } \\
\text { school }\end{array}$ & $\begin{array}{l}\text { Secondar } \\
\text { y school }\end{array}$ & Inter & $\begin{array}{l}\text { Degree } \\
\text { Continuin } \\
\text { g }\end{array}$ \\
\hline N \& \% & N \& \% & N \& \% & N \& \% & N \& \% \\
\hline $\mathbf{5}(\mathbf{7 \%})$ & $17(22 \%)$ & $27(36 \%)$ & $23(31 \%)$ & $3(4 \%)$ \\
\hline
\end{tabular}

Table.3 Occupation wise distribution of the Selected sample $(\mathrm{N}=75)$

\begin{tabular}{|c|c|c|c|}
\hline $\begin{array}{l}\text { House } \\
\text { wife } \\
\text { N \& \% }\end{array}$ & $\begin{array}{l}\text { Fully } \\
\text { involved in } \\
\text { agriculture } \\
\text { N \& \% }\end{array}$ & $\begin{array}{l}\text { Partially } \\
\text { involved in } \\
\text { agriculture } \\
\mathrm{N} \& \%\end{array}$ & $\begin{array}{l}\text { Petit } \\
\text { business } \\
\text { N \& \% }\end{array}$ \\
\hline $9(12 \%)$ & $33(44 \%)$ & $28(37 \%)$ & $5(7 \%)$ \\
\hline
\end{tabular}

Table.4 Socio Economic Status of the sample $(\mathrm{N}=75)$

\begin{tabular}{|l|c|r|}
\hline $\begin{array}{l}\text { Socio economic } \\
\text { status } \\
\text { classification }\end{array}$ & Score & $\begin{array}{l}\text { Rural mothers with } \\
\text { children between 2 - } \\
\text { 5 yrs (N=75) }\end{array}$ \\
\hline Upper High & $>76$ & --- \\
\hline High & $61-75$ & $\mathbf{2}(\mathbf{3 \% )}$ \\
\hline Upper middle & $46-60$ & $\mathbf{1 3}(\mathbf{1 7 \%})$ \\
\hline Lower middle & $31-45$ & $\mathbf{4 5}(\mathbf{6 0})$ \\
\hline Poor & $16-30$ & $\mathbf{1 5}(\mathbf{2 0 \% )}$ \\
\hline Very poor & $<15$ & ---- \\
\hline
\end{tabular}


Table.5 Reproductive Health Knowledge scores of Rural mothers with children (between 2 -5 years) - Pretest scores

\begin{tabular}{|c|c|c|c|c|}
\hline S.no & $\begin{array}{l}\text { Reproductive Health } \\
\text { awareness dimensions }\end{array}$ & Category & Score & $\begin{array}{l}\text { Rural mothers with children } \\
\text { (between } 2-5 \text { years) } N=75 \text { (No \& \%) }\end{array}$ \\
\hline \multirow[t]{3}{*}{ A } & \multirow{3}{*}{$\begin{array}{l}\text { Preconception Health }(26 \\
\text { statements) }\end{array}$} & High & $53-78$ & $20(27 \%)$ \\
\hline & & Average & $27-52$ & $44(58 \%)$ \\
\hline & & Low & $<26$ & $11(15 \%)$ \\
\hline \multirow[t]{3}{*}{ B } & \multirow{3}{*}{$\begin{array}{l}\text { Reproductive health } \\
\text { problems (30 statements) }\end{array}$} & High & $61-90$ & $28(37 \%)$ \\
\hline & & Average & $31-60$ & $39(52 \%)$ \\
\hline & & Low & $<30$ & $8(11 \%)$ \\
\hline \multirow[t]{3}{*}{$\mathrm{C}$} & \multirow{3}{*}{$\begin{array}{l}\text { Family planning }(17 \\
\text { statements) }\end{array}$} & High & $35-51$ & $26(35 \%)$ \\
\hline & & Average & $18-34$ & $39(52 \%)$ \\
\hline & & Low & $<17$ & $10(13 \%)$ \\
\hline \multirow[t]{3}{*}{$\mathrm{D}$} & \multirow{3}{*}{$\begin{array}{l}\text { Sexually transmitted } \\
\text { diseases(36 statements) }\end{array}$} & High & $73-108$ & $28(37 \%)$ \\
\hline & & Average & $37-72$ & $34(45 \%)$ \\
\hline & & Low & $<36$ & $13(18 \%)$ \\
\hline \multirow[t]{3}{*}{$\mathrm{E}$} & \multirow[t]{3}{*}{ General (30 statements) } & High & $61-90$ & $13(17 \%)$ \\
\hline & & Average & $31-60$ & $41(55 \%)$ \\
\hline & & Low & $<30$ & $21(28 \%)$ \\
\hline
\end{tabular}

Table.6 Reproductive Health Knowledge scores of Rural mothers with children (between 2 -5 years) - Post assessment Scores

\begin{tabular}{|c|c|c|c|c|}
\hline s.no & $\begin{array}{l}\text { Reproductive Health } \\
\text { awareness dimensions }\end{array}$ & Category & Score & $\begin{array}{c}\text { Rural mothers with children } \\
\text { (between } 2-5 \text { years) } N=75 \text { (No \& \%) }\end{array}$ \\
\hline \multirow[t]{3}{*}{ A } & \multirow{3}{*}{$\begin{array}{l}\text { Preconception Health } \\
\text { (26 statements) }\end{array}$} & High & $53-78$ & $45(60 \%)$ \\
\hline & & Average & $27-52$ & $29(39 \%)$ \\
\hline & & Low & $<26$ & $1(1 \%)$ \\
\hline \multirow[t]{3}{*}{ B } & \multirow{3}{*}{$\begin{array}{l}\text { Reproductive health } \\
\text { problems ( } 30 \text { statements) }\end{array}$} & High & $61-90$ & $36(48 \%)$ \\
\hline & & Average & $31-60$ & $35(47 \%)$ \\
\hline & & Low & $<30$ & $4(5 \%)$ \\
\hline \multirow[t]{3}{*}{$\mathrm{C}$} & \multirow{3}{*}{$\begin{array}{l}\text { Family planning }(17 \\
\text { statements })\end{array}$} & High & $35-51$ & $40(53 \%)$ \\
\hline & & Average & $18-34$ & $33(44 \%)$ \\
\hline & & Low & $<17$ & $2(3 \%)$ \\
\hline \multirow[t]{3}{*}{$\mathrm{D}$} & \multirow{3}{*}{$\begin{array}{l}\text { Sexually transmitted } \\
\text { diseases(36 statements) }\end{array}$} & High & $73-108$ & $37(49 \%)$ \\
\hline & & Average & $37-72$ & $33(44 \%)$ \\
\hline & & Low & $<36$ & $5(7 \%)$ \\
\hline \multirow[t]{3}{*}{$\mathrm{E}$} & \multirow[t]{3}{*}{ General (30 statements) } & High & $61-90$ & $42(56 \%)$ \\
\hline & & Average & $31-60$ & $30(40 \%)$ \\
\hline & & Low & $<30$ & $3(4 \%)$ \\
\hline
\end{tabular}


Table.7 Reproductive health Knowledge scores (Pre \& Post) Rural mothers with children (between $2-5$ yrs) $\mathrm{N}=75$

\begin{tabular}{|c|c|c|c|c|c|c|c|c|c|}
\hline \multirow[t]{2}{*}{ Dimensions } & \multirow{2}{*}{$\begin{array}{l}\text { Sub- } \\
\text { Dimensions }\end{array}$} & \multicolumn{2}{|c|}{ Raw scores } & \multicolumn{2}{|c|}{ Mean } & \multicolumn{2}{|c|}{ SD } & \multirow{2}{*}{$\begin{array}{c}\text { Mean } \\
\text { differences } \\
(\mathrm{P} 1-\mathrm{P})\end{array}$} & \multirow[t]{2}{*}{$\mathrm{T}$ value } \\
\hline & & (P) & (P1) & (P) & (P1) & (P) & (P1) & & \\
\hline \multirow{5}{*}{$\begin{array}{l}\text { 1. Pre- } \\
\text { conception } \\
\text { Health } \\
\text { (includes } 4 \\
\text { dimensions) }\end{array}$} & $\mathrm{A}(\mathrm{PP})$ & 933 & 1058 & 12.44 & 14.11 & 3.30 & 3.48 & 1.67 & $4.39 * *$ \\
\hline & $\mathrm{B}(\mathrm{PCH})$ & 1035 & 1205 & 13.8 & 16.07 & 3.51 & 3.52 & 2.27 & $9.51 * *$ \\
\hline & $\mathrm{C}(\mathrm{PP})$ & 647 & 761 & 8.63 & 10.15 & 2.28 & 2.18 & 1.52 & $6.06^{* *}$ \\
\hline & $\mathrm{D}(\mathrm{PB})$ & 819 & 964 & 10.92 & 12.85 & 3.08 & 2.74 & 1.93 & $2.17 * *$ \\
\hline & Total & 3434 & 3988 & 45.79 & 53.17 & 11.17 & 10.37 & 7.38 & $5.01 * *$ \\
\hline \multirow{5}{*}{$\begin{array}{l}2 . \\
\text { Reproductive } \\
\text { health } \\
\text { problems } \\
\text { (includes } 4 \\
\text { dimensions) }\end{array}$} & A (MP) & 1192 & 1231 & 15.89 & 16.41 & 4.66 & 4.40 & 0.52 & $0.06 \mathrm{NS}$ \\
\hline & B (MHP) & 817 & 873 & 10.89 & 11.64 & 3.36 & 3.01 & 0.75 & $1.04 * *$ \\
\hline & C (PR-MH) & 552 & 594 & 7.36 & 7.92 & 2.11 & 2.08 & 0.56 & $0.03 \mathrm{NS}$ \\
\hline & $\mathrm{D}(\mathrm{GP})$ & 1728 & 1786 & 23.04 & 23.81 & 6.10 & 6.24 & 0.77 & $0.04 \mathrm{NS}$ \\
\hline & Total & 4289 & 4484 & 57.19 & 59.79 & 14.42 & 13.95 & 2.6 & $8.25^{* *}$ \\
\hline \multirow{4}{*}{$\begin{array}{l}\text { 3. Family } \\
\text { planning } \\
\text { (includes } 3 \\
\text { dimensions) }\end{array}$} & $\mathrm{A}(\mathrm{FPM})$ & 666 & 768 & 8.88 & 10.24 & 2.81 & 2.70 & 1.36 & $1.28^{* *}$ \\
\hline & B (PFPM) & 562 & 631 & 7.49 & 8.41 & 2.48 & 2.17 & 0.92 & $7.92 * *$ \\
\hline & $\mathrm{C}(\mathrm{CP})$ & 1120 & 1208 & 14.93 & 16.11 & 4.42 & 4.10 & 1.18 & $0.03 \mathrm{NS}$ \\
\hline & Total & 2348 & 2607 & 31.31 & 34.76 & 8.49 & 7.88 & 3.45 & $5.35^{* * *}$ \\
\hline \multirow{6}{*}{$\begin{array}{l}\text { 4. Sexually } \\
\text { transmitted } \\
\text { diseases } \\
\text { (includes } 5 \\
\text { dimensions) }\end{array}$} & A (HIV/AIDS) & 1038 & 1076 & 13.84 & 14.35 & 3.77 & 4.04 & 0.51 & $0.04 \mathrm{NS}$ \\
\hline & B (RTI/STD) & 1367 & 1453 & 18.22 & 19.37 & 4.54 & 4.55 & 1.15 & $3.61 * *$ \\
\hline & $\begin{array}{l}\mathrm{C}(\mathrm{T}- \\
\text { HIV/AIDS) }\end{array}$ & 1243 & 1361 & 16.57 & 18.15 & 5.05 & 4.95 & 1.58 & $9.94 * *$ \\
\hline & $\begin{array}{l}\text { D (PM- } \\
\text { HIV/AIDS) }\end{array}$ & 440 & 465 & 5.87 & 6.2 & 2.04 & 1.93 & 0.33 & $0.03 \mathrm{NS}$ \\
\hline & $\begin{array}{l}\text { E (PM - } \\
\text { RTI/STD) }\end{array}$ & 729 & 760 & 9.72 & 10.13 & 3.13 & 2.99 & 0.41 & $0.03 \mathrm{NS}$ \\
\hline & Total & 4817 & 5115 & 64.23 & 68.2 & 16.82 & 16.23 & 3.97 & $1.04 * *$ \\
\hline \multirow{4}{*}{$\begin{array}{l}\text { 5. General } \\
\text { (includes } 3 \\
\text { dimensions) }\end{array}$} & A (RHS) & 1213 & 1373 & 16.17 & 18.31 & 4.88 & 5.56 & 2.14 & $2.02 * *$ \\
\hline & B (M\&LR) & 1142 & 1420 & 15.23 & 18.93 & 5.09 & 4.83 & 3.7 & $2.46^{* *}$ \\
\hline & $\mathrm{C}(\mathrm{RR})$ & 1459 & 1779 & 19.45 & 23.72 & 6.79 & 6.34 & 4.27 & $2.37 * *$ \\
\hline & Total & 3814 & 4572 & 50.85 & 60.96 & 15.66 & 15.49 & 10.11 & $7.75^{* *}$ \\
\hline
\end{tabular}




\section{Abbreviations}

\begin{tabular}{|c|c|c|c|c|c|}
\hline $\begin{array}{l}\text { 1. Pre- } \\
\text { conception } \\
\text { Health }\end{array}$ & $\begin{array}{l}\text { A:Preparation for } \\
\text { Parenthood }\end{array}$ & $\begin{array}{l}\text { B:Factors that Boost } \\
\text { Preconception } \\
\text { Health }\end{array}$ & $\begin{array}{l}\text { C:Preparedness for } \\
\text { pregnancy }\end{array}$ & $\begin{array}{l}\text { D:Preconcepti } \\
\text { on Behaviours }\end{array}$ & ------- \\
\hline $\begin{array}{l}2 . \\
\text { Reproductiv } \\
\text { e health }\end{array}$ & $\begin{array}{l}\text { A:Menstrual } \\
\text { problems }\end{array}$ & $\begin{array}{l}\text { B:Menstrual } \\
\text { hygiene practices }\end{array}$ & $\begin{array}{l}\text { C:Potential risks to } \\
\text { health due to poor } \\
\text { menstrual hygiene }\end{array}$ & $\begin{array}{l}\text { D:Gynecologi } \\
\text { cal problems }\end{array}$ & ---------- \\
\hline $\begin{array}{l}\text { 3. Family } \\
\text { planning }\end{array}$ & $\begin{array}{l}\text { A:Family Planning } \\
\text { Methods }\end{array}$ & $\begin{array}{l}\text { B:Purpose of } \\
\text { following Family } \\
\text { planning methods }\end{array}$ & $\begin{array}{l}\text { C:Contraceptive } \\
\text { related problems }\end{array}$ & ---------- & \\
\hline 4. STD & $\begin{array}{l}\text { A:Awareness about } \\
\text { HIV/AIDS \&related } \\
\text { problems }\end{array}$ & $\begin{array}{l}\text { B:Awareness about } \\
\text { RTI/STD related } \\
\text { problems }\end{array}$ & $\begin{array}{l}\text { C:Awareness about } \\
\text { transmission of } \\
\text { HIV / AIDS }\end{array}$ & $\begin{array}{l}\text { D:Preventive } \\
\text { methods for } \\
\text { HIV/AIDS }\end{array}$ & $\begin{array}{l}\text { E:Preventive } \\
\text { methods for } \\
\text { RTI/STD }\end{array}$ \\
\hline 5. General & $\begin{array}{l}\text { A:Services Related } \\
\text { to Reproductive } \\
\text { Health }\end{array}$ & $\begin{array}{l}\text { B:Awareness about } \\
\text { marital laws \& } \\
\text { legal rights }\end{array}$ & $\begin{array}{l}\text { C:Awareness about } \\
\text { Reproductive rights }\end{array}$ & --------- & ---------- \\
\hline
\end{tabular}
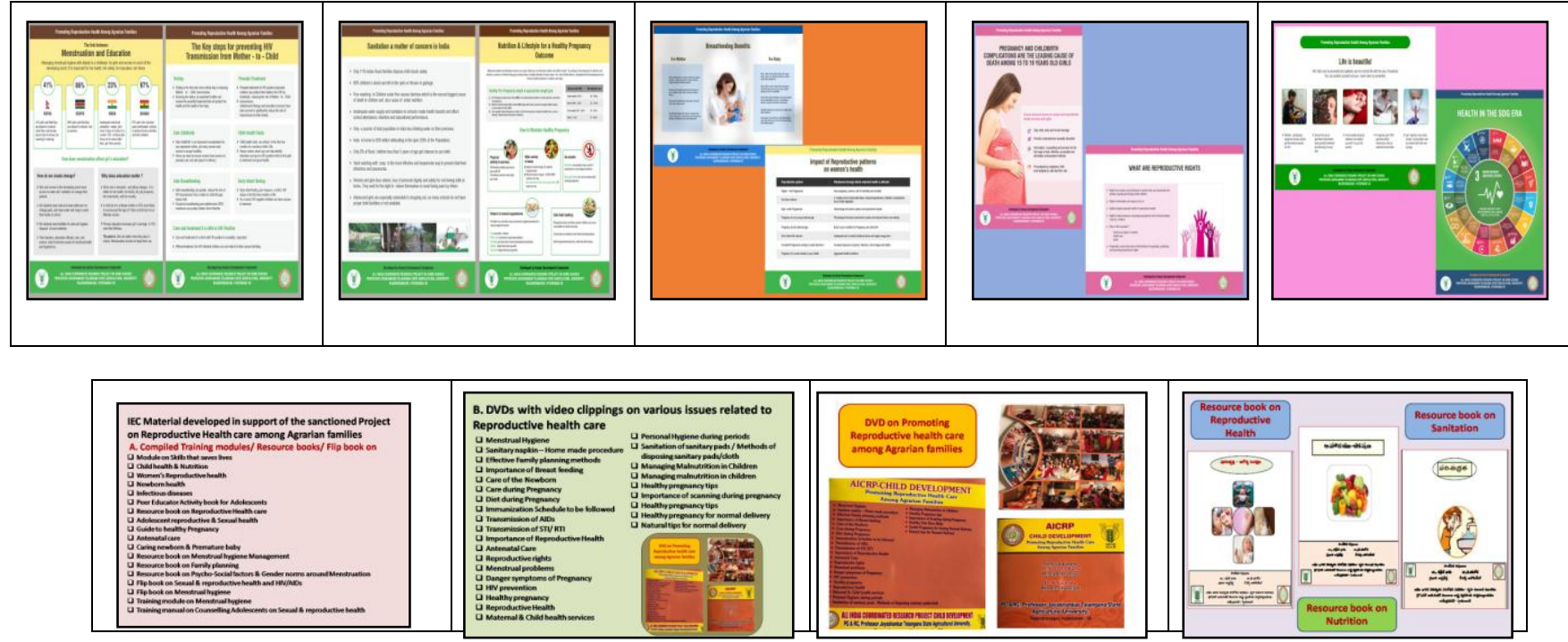

\section{Capacity building programmes}

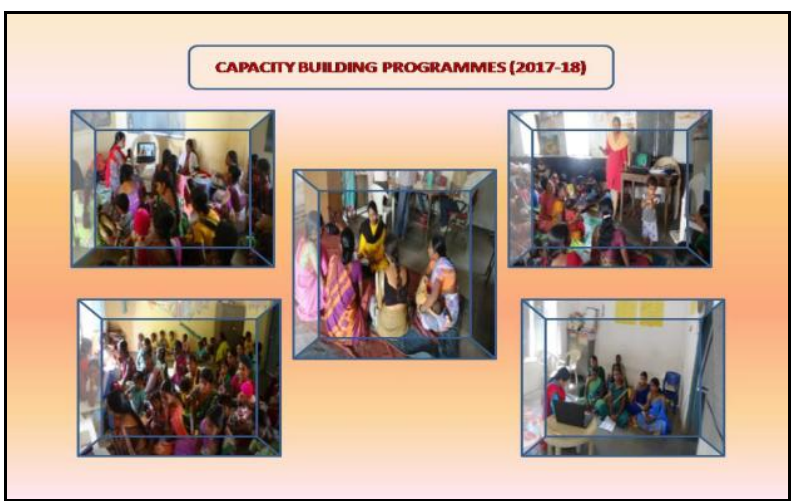


Reproductive Health knowledge scores of Rural mothers with children (between 2-5 years) - Dimension \& category wise

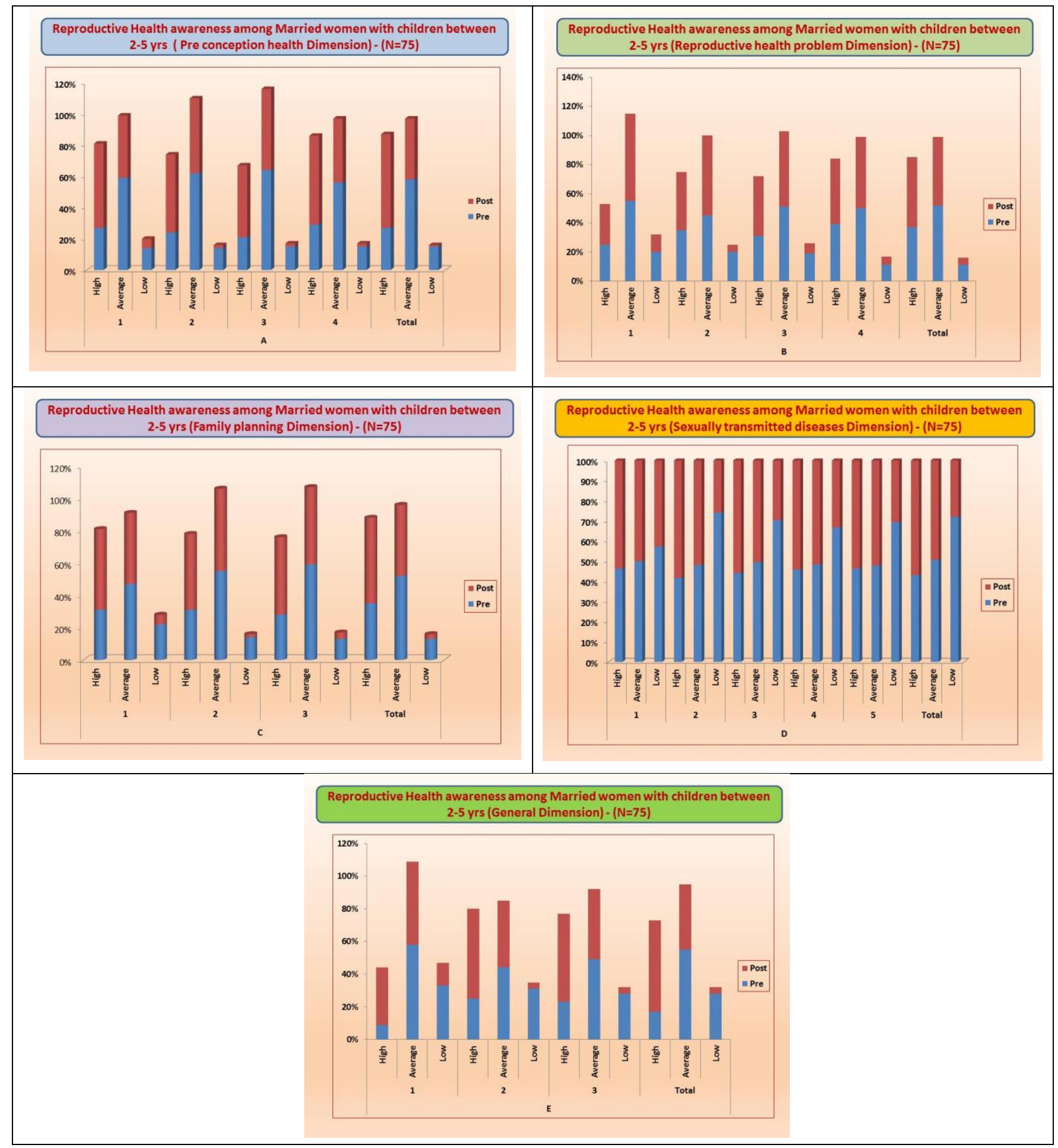




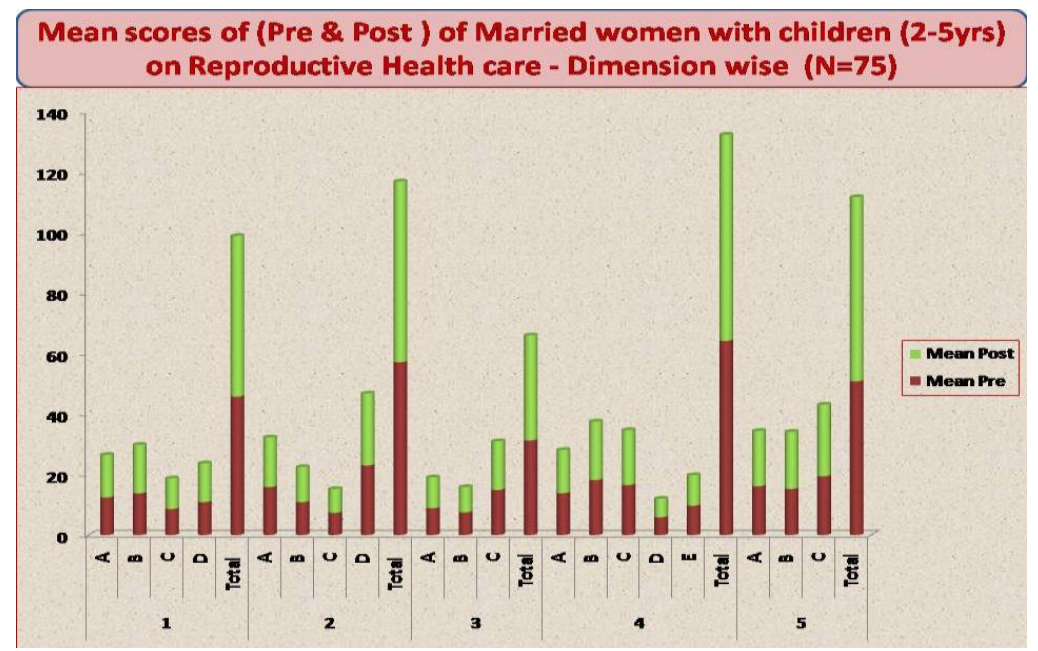

With regard to General dimension, more than half $(56 \%)$ of the sample obtained High scores; $40 \%$ obtained Average scores and only $4 \%$ obtained Low scores.

The table 7 presents the Pre \& Posttest (Raw scores, Means, SD and T values) Scores of Married women (with children between 2-5 yrs) with regard to Sub-dimensions under Reproductive Health Care. The table shows the progressive increase in the total raw scores across pre-test to post-test, along with the increase in the mean differences, which shows the impact of intervention programme.

$\mathrm{T}$ values between the two means of pre-test and post-test was found to be highly significant, as the calculated values were found to be greater than the tabulated value. The results reflect the effectiveness of Intervention programmes on the Knowledge levels of Married women with reference to Reproductive Health.

In conclusion, rural Indian women need accurate health education about Gynecologic and reproductive morbidity to reduce the stigma and embarrassment of RTIs. Health services should be improved and made more accessible so that women feel comfortable in seeking treatment and are not deterred by concerns over privacy and confidentiality.
Women tend to consider many symptoms as normal, do not seek treatment until discomfort is quite high and so apparently remain infected for a long time.

In India, married women, lack basic knowledge about reproductive health and HIV. Gender inequalities affect their capacity to influence when, where and how sexual relations should form, rendering them vulnerable to coerced or unwanted sex, and placing them at high risk for adverse reproductive health outcomes. Hence Intervention is very much needed to promote reproductive health among married women.

\section{Acknowledgement}

The present study was supported by ICAR under XIII plan period.

\section{References}

Santow, G.1995. "Social roles and physical health: The case of female disadvantage in poor countries", Social Science and Medicine 40(2), pp.147-61.

Santhya, G.K and Jejeeboy, J.S., (2003).Sexual and reproductive health of married adolescent girls. Economic and Political Weekly, 38 (41): 4370-76. 
Singh, K.S., Prasad, R., Verma, B.R. and Pandey, A. (1995). Psychosocial cultural and service factors affecting reproductive morbidity among rural women in Maharashtra. International Institute for Population Sciences, pp. 1-
26.

Singh, AJ. (2004). Mobile clinic approach to tackle reproductive health problem of women in north India. Bull PGI, 2004: 38-66-70.

\section{How to cite this article:}

Nasreen Banu and Yashoda, K. 2018. Impact of Intervention on Reproductive Health knowledge of Rural Mothers. Int.J.Curr.Microbiol.App.Sci. 7(11): 1957-1968.

doi: https://doi.org/10.20546/ijcmas.2018.711.222 